\title{
Pathologies of Recognition: An Introduction
}

\section{by Arto Laitinen, Arvi Särkelä and Heikki Ikäheimo}

This special issue focuses on two central concepts in contemporary critical social theory: namely 'recognition' and 'social pathology'. For defenders of a theory of recognition, adequate recognition is itself a key normative criterion for analysing social wrongs and pathologies which fall short of the ideal. For critics, the focus on recognition - even at its best - rather conceals social wrongs. While the contributors in this collection represent slightly different approaches, the general consensus amongst them is that recognition as such is a good ideal but like all good ideals it can go wrong in various ways and take pathological forms itself. The papers published here are part of a larger project that can be thought of as continuing what has been called the 'Jyväskylä school' of recognition theories. ${ }^{1}$

In the first subsection we briefly introduce the notion of recognition and trace its development from Fichte and Hegel to Honneth and his critics, and in the second subsection turn to the concept of a social pathology. The third section provides a brief look at the individual papers.

\section{Recognition from Hegel to Honneth and His Critics}

As much as it is agreed upon that recognition (Anerkennung) is of vital importance for humans individually and collectively and that the lack of it can therefore have serious consequences, the dynamics of the lack or denial of recognition have not been extensively discussed in the literature.

On the trail of investigation starting from the post-Kantian German philosophers Fichte and Hegel, recognition is a central distinguishing factor of human sociality and thereby of both psychological and social structures defining the human life-form. With some differences, both Fichte and Hegel conceived of recognition as consisting of intersubjective attitudes whereby individual structures of consciousness or intentionality become mediated by those of other individuals, and whereby fundamental social relations and structures come about. Through recognition of others, human individuals begin to relate to themselves and their environment both epistemically and motivationally partly from the perspectives of the others they recognize, grasping themselves as Is and yous and thereby forming various basic kinds of 'we'-groups. Writing before Darwin, neither philosopher had a picture of 
the phylogenetic details of this phenomenon in the natural history of the human species, but both had ideas about how it works ontogenetically in the development of human infants in already 'humanized' societies. Most importantly, they, and especially Hegel, developed conceptual tools that marked the beginning of a paradigm for thinking about distinctively human psychological and social capacities, patterns and structures as an interconnected whole: a paradigm with great theoretical promise and a close connection to everyday experiences of 'recognition' and the lack of it.

In addition to pioneering a way of thinking about distinctively human psychological and social capacities and structures in a unified way, the forefathers of the recognition-paradigm also opened up ways to synthetize a purely descriptive account of the human life-form with a broad range of normative considerations, ranging from purely functional considerations to legal, moral, and political ones. In a nutshell: as they conceived of it, recognition is not only ontologically necessary for the existence of structures and capacities distinctive of the human life-form, it is also fundamental to their functioning, as well as to the well-being of individuals and the ethical or moral quality of their relationships, characters, motives and actions. On Fichte's (2000 [1796]) account, the process through which the human infant gradually develops from a helpless animal into a self-conscious, rational and autonomous being - or, as he says, a 'person' - involves mutual recognition in the sense of attributing normative statuses to others and conceiving of oneself and others as bound by these. One way to reconstruct Fichte's thinking (see Ikäheimo, 2014, chapter 3) is to understand recognition as mutual attribution of authority over rules or norms of interaction and thereby coming to conceive of oneself as an individual bound by norms and responsible to others. Thus, mutual attribution of authority is needed for establishing and administering a space of shared norms or rules. For Fichte this is the basic ontological structure of the human life-form and simultaneously the foundation of both the legal realm and of morality. Importantly, this amounts to conceiving of morality as an inbuilt element of the basic structure of human sociality.

One of Hegel's many additions to the ideas of intersubjective recognition pioneered by Fichte was to think of the phenomenon in a more differentiated way, as having more than one form or dimension (see Honneth, 1995). ${ }^{2}$ Whereas Fichte understood recognition in merely deontological terms, as establishing a space of norms and thereby rights and the duties they imply (or, as he writes, 'a relationship of right'), Hegel added a second - axiological - dimension of recognition in which intersubjective recognition brings about a mediation of the individual's motivational or value-horizon through the value-horizons of others. To recognize in this 
axiological sense - which Hegel, following certain other post-Kantian thinkers, calls 'love' (Liebe) - is to care for or to be moved by the well-being of others non-instrumentally and thus to internalize their concerns as if they were one's own concerns. Analogically to the Fichtean deontological form of recognition, this axiological form of recognition thus also introduces an intersubjective mediation to the structure of intentionality or consciousness of the individual, and it also adds a second dimension to the idea that recognition is of fundamental moral or ethical significance.

Another originally Hegelian innovation, one which has had a profound influence in social and political thought, is the addition of a conflictual aspect to the notion of intersubjective recognition. Hegel's famous parable of 'master and slave' illustrates the internal structure, dynamics and tendency to self-overcoming of one-sided recognition, of being recognized by others without having recognition for them or vice versa. In ways that have also found resonance in 20th century psychological and psychoanalytical thinking (see Benjamin, 1988), Hegel presents the figure of the 'master' as one who demands recognition from others (the 'slaves') of his absolute authority over them (the deontological dimension of recognition) without recognizing them as having any authority over him (or anyone else), and who demands recognition from others for his well-being as having absolute value (the axiological dimension of recognition) without recognizing their well-being as having any value that is non-instrumental. Although Hegel is, generally speaking, optimistic about the functional dynamics of one-sided recognition-relations eventually leading to more equal relations of recognition, his introduction of the conflictual, egoistic, or 'negative' side of desires and relations of recognition does complicate the picture and for many readers introduces an element of psychological realism into it.

After its inception by Fichte and Hegel the idea of recognition has played many roles in social and political thought as well as in psychology from an almost unconscious influence in Marx, Lukács and others in the leftHegelian tradition, surfacing here and there in the social theory of British neo-Hegelians such as Bosanquet and pragmatists such as Dewey and Mead, to being the central concept in Alexandre Kojève's anthropological philosophy of history and thereby massively influencing 20th century French thought, including the Lacanian school of psychoanalysis and Sartrean existentialism. Yet only during the last 20 years has recognition become a topic of widespread and focused discussions in social and political philosophy, as well as a topic of systematic philosophical investigation.

These discussions have largely concentrated on issues of multiculturalism and various kinds of 'politics of identity' with the guiding 
idea that linguistic, ethnic, sexual and other particular identity-defining features require 'recognition' in the form of not only legal support but also positive societal appreciation. What is new in these debates is, first, the introduction of a third form of recognition - positive appreciation or valuation of particular features of individuals and groups - and, secondly, a close connection to actual political movements, struggles and discourses (among the central texts here are Taylor, 1994 and Fraser, 1995). However, these discussions have tended to de-emphasize the Fichtean and Hegelian ideas of the foundational significance of recognition for distinctively human psychological and social structures, as well as the fundamentally moral or ethical nature of recognition.

Generally acknowledged as presenting the most ambitious agenda in contemporary social and political philosophy utilizing the idea of recognition, and one with major importance for this special issue, Axel Honneth (1995) presents the outlines of a 'formal theory of the good life' whose aim is to normatively evaluate the basic institutions of societies according to how well they enable the development and maintenance of the psychological resources that individuals need for autonomous and subjectively meaningful self-realization. The idea - drawing on an interpretation of Hegel and modern developmental psychology and psychoanalysis - is that essential to such psychological resources are the positive self-relations of self-trust, self-respect and self-esteem, and that these positive self-relations are dependent on experiences of being an object of the corresponding three forms of recognition of love, respect and esteem by relevant others. Thus in Honneth's view a society is good to the extent that its basic institutions allow for, facilitate or embody these different forms of recognition and thereby support psychological well-being and individual self-realization. Honneth also draws heavily on the Hegelian idea of 'struggles' for recognition leading to better or more equal forms and relations of recognition.

With all its merits, Honneth's project has drawn criticism from various sides. Much of the criticism has accused the project of uncritical optimism regarding the content and results of demands and struggles of recognition. For example:

A) Many have claimed that Honneth does not propose adequate means for distinguishing good from bad (i.e. morally or politically unjustifiable) desires, expectations and demands for recognition (Fraser in Fraser \& Honneth, 2003). 
B) There has been widespread scepticism about Honneth's alleged Hegelian optimism about struggles for recognition leading by default to social and moral progress.

C) Relying on particular strands in developmental psychology and psychoanalysis, Honneth introduces a relatively harmonistic picture of the psychodynamics of recognition the details of which are controversial (Butler, 2008; Whitebook, 2009). Related to that, Honneth's Hegelian conceptualization of recognition as consisting of the positive (moral or ethical) attitudes of respect, love and esteem has been challenged by more 'pessimistic' conceptualizations that emphasize the necessity of issues like power-relations in the very dynamic of recognition (Butler, 2008; Whitebook, 2009). It remains contested why one should choose Honneth's 'harmonistic' or 'optimistic' conceptualization of intersubjective recognition over more 'agonistic' or 'pessimistic' ones.

D) Honneth, alongside many others in the recognition-theoretical stream of thought, has emphasized an inbuilt need for recognition in humans, but this idea has not been systematically combined or contrasted with an account of reasons that individuals and groups may have for denying or rejecting recognition. This, one might argue, makes the overall picture too optimistic and results in insufficient diagnostic power for understanding the dynamics, reasons for, and possible outcomes of situations where recognition between individuals or groups is not forthcoming.

This special issue addresses some of these worries, and thereby aims to contribute to the further development of the recognition-theoretical paradigm in social and political philosophy. It accepts as a working hypothesis the two programmatic ideas of the founders of the recognitionparadigm: a) that intersubjective recognition is of fundamental constitutive significance for distinctively human psychological and social structures, and b) that it is of fundamental significance for these structures to function well, for the well-being and freedom of individuals, and for the moral or ethical quality of their relationships, characters, motives and actions.

The contributions to this issue will critically complement the Hegelinspired picture outlined by Honneth and others following him of successful relationships of recognition and their generally optimistic conception of the content, dynamics and results of needs, demands and struggles for recognition with an account of denied, lacking or rejected recognition. The papers examine psychological and social factors that may lead to the lack, denial or rejection of recognition and the potential consequences these may 
have. As recognition is, arguably, of constitutive significance for the psychological and social reality of humans, and as failures of recognition may therefore have serious psychologically and socially pathological or destructive consequences, it is essential to have an adequate philosophical and theoretical grasp of this negative side of recognition-relationships as well.

In the spirit of Immanuel Kant's idea of 'asocial sociability,' the papers in this collection will in different ways critically complement the aforementioned idea that humans have an inbuilt need for recognition with the general hypothesis that due to the very nature of recognition, there are also universally human tendencies to the denial or rejection of recognition (see most explicitly Ikäheimo's paper 'Conceptualizing Causes for Lack of Recognition-Capacities, Costs, and Understanding'). Thus, although humans need intersubjective recognition to exist and flourish as human persons individually and collectively, they are also equipped with mechanisms that present a constant threat to this condition being fulfilled and thus to their existence and well-being. This can be thought of in terms of specific kinds of psychological vulnerabilities and costs that recognition and thus the recognition-dependence of humans introduce.

For example, taking others as having authority over one makes one vulnerable to their judgments, including negative ones. It makes sense that there would also be defensive tendencies to avoid psychic costs by denying recognition to others as authorities. Being concerned for the well-being of others, and loving them, makes one vulnerable to their suffering. The more one cares the deeper one can be hurt and this introduces clear limits to the individual's capacity to love or care intrinsically. The capacity of repressing one's concern for others as a defence mechanism would not be a surprising part of the normal psychic makeup of individuals. And acknowledging the value of the contributions by others or one's dependence on them may be a blow to one's self-image, creating anxiety and again necessitating defence mechanisms. Interestingly, in addition to these tendencies to repress one's recognition for others or deny it to them, there may well be tendencies to try to reject the significance of the recognition one gets or fails to get from others. This is easy to see in cases of negative judgements one would like to avoid, but accepting positive judgements may be experienced as taking part in a social dynamic that is threatening in other ways - by opening oneself to the views of others, one risks being vulnerable in a new way. There may be a number of psychological, institutional and/or cultural factors that play a role in determining how open or closed people are to relations of mutual recognition.

While various factors that shed light on tendencies to suppress mutual 
recognition need to be studied by means of empirical research, theories about the very nature of mutual recognition can help clarify the intersubjective dynamics of mutual misrecognition. It is rewarding to be recognized, and being recognized in turn motivates the recognizing of others. Similarly, experiences of misrecognition motivate one to deny recognition to others, as it is easy to spot in downward spirals of revenge or in frozen conflicts. After such violations, it is very hard to repair the relationships, and very easy to deepen the harms. The psychology of group processes reveals how easily the division into 'us' and 'them' emerges, and unfortunately such division does not go away as easily: when a division becomes operative, especially in a negative way, it will have a dynamic of its own. One way to conceptualize such negative developments of relations of recognition is as 'social pathologies.'

\section{Social Pathologies}

Among the social pathologies discussed in the tradition of critical theory are such social evils as reification, alienation, invisibilization, ideological social practices including ideological recognition, distributive injustice, social inequality, economic exploitation and pathologies of rationality. Whether these are indeed pathologies of recognition is contestable and depends on to the extent to which they can be understood to denote different ways in which social reality fails to actualize adequate recognition. Further, one may ask whether the dynamics of misrecognition can generate a distinct kind of pathology, which is not best grasped in terms of these other traditional social evils.

There are several questions that an account of social pathologies should answer. One is why philosophers should characterize social evils with this concept at all, as it comes with notable historical baggage, having medical, biological, and psychiatric connotations and a strong hint of 'organismic' conceptions of society (see Honneth, 2014b). To attempt an answer, let us distinguish three different conceptions of a social pathology that each accept that social pathologies are something pervasive and (at least partly) socially caused. ${ }^{3}$ The first view A) studies the shared conceptual structure of the pathologies without stressing the medical, biological or organismic aspect of the concept, the second B) takes seriously the idea of a social organism and the third C) builds on the crucially different idea of the process of social life.

A) One may try to define social pathologies without any organismic hints by suggesting that what makes social evils 'pathologies' is that they share a 
particular relational conceptual structure, as suggested by Christopher Zurn's (2011) interpretation of Axel Honneth's (and the Frankfurt School's critical theory's) writings. Zurn characterizes pathologies as socially caused and pervasive 'second-order disorders'. By this he means that in cases such as reification, invisibilization and ideological recognition one finds 'constitutive disconnects between first-order contents and second-order reflexive comprehension of those contents, where those disconnects are pervasive and socially caused' (Zurn, 2011, 345-6). This proposal is critically discussed in the chapter by Laitinen.

Explicitly referring to Zurn, Axel Honneth draws upon a structure much like this in his Freedom's Right. He describes social pathologies as the ways in which one-sided conceptions of freedom, such as juridical freedom and moral freedom, necessarily distort recognitive relationships if they are taken to be authoritative as such and are not integrated within a more inclusive picture of social freedom (Honneth, 2014a, part II). Here, again, the pathology is that the first-order content of social practice is not fully grasped by conceptions of juridical and moral freedom on the level of second-order reflection, making the practice not only one-sidedly comprehended but also intrinsically distorted.

On this reading, the naturalist or medical connotations of 'pathology' do not seem important for the implementation of the concept within social phenomena. Even if the concept of pathology here is clearly intended as a critical tool for diagnosing social disorders not grasped thoroughly enough by 'mere' moral or political criticism, this view of pathologies of recognition is thus not immediately tied to the wider pathology diagnostic tradition in social philosophy that Honneth traces back to Rousseau in his early essay on 'Pathologies of the Social' (cf. Honneth, 2007). One advantage here is that the concept of pathology seems a handy way of distinguishing the project of 'critical social philosophy' from the projects of 'political philosophy' or 'moral philosophy' that apply standards of legitimacy and moral rightness on social conditions. An intuition behind this use of the concept of pathology seems to be that it adds a distinct layer of social wrongs or evils to the picture. Under pathological conditions, the questions of moral rightness and political legitimacy appear as one-sided and do not grasp the specific disorder addressed. ${ }^{4}$

A difficulty might be that the concept risks ending up as too abstract: firstly, it is not clear whether such diverse phenomena as ideology, reification, invisibilization, organized self-realization, etc. can be understood as having one common conceptual structure of 'second-order disorders' (see Laitinen's 'Social Pathologies, Reflexive Pathologies, and the Idea of Higher Order Disorders' below in this collection, as well as Freyenhagen, 2015). This 
worry can perhaps be avoided by having a more encompassing view about the shared conceptual structure of social pathologies, reserving the term 'reflexive pathologies' for Zurn's proposal, but other open issues remain.

Secondly, it seems that according to this view the terminology of 'pathologies' remains an optional - and perhaps in some sense misleading way to speak about pervasive forms of ideologically concealed socially caused suffering. There seem to be no really compelling reasons why these social evils be called 'pathologies,' as the word comes with a historically loaded significance much more specific than the relational 'second-order disorder'-structure. Arguably, something that is central to influential diagnoses of pathology seems to be missing in this picture. For instance, Hegel's story of 'Lord and Bondsman,' Adorno's concept of 'damaged life,' and even Durkheim's diagnosis of 'anomie' all clearly share a fundamentally pathology-diagnostic claim, yet their diagnoses do not necessarily feature a disconnect between first and second orders. This disconnect is thematized by all three authors by means of 'subconcepts' (of 'ideology critique' perhaps) such as 'Stoicism, Skepticism and Unhappy Consciousness' in Hegel's case, 'Verblendungszusammenhang' in Adorno, and 'market individualism' in Durkheim. Only in the case of these ideology-analytical 'subconcepts' do we have an explicit thematization of a necessary disconnect of first-order contents and second-order reflection. Pathology can conceptually go on without them in all three authors' accounts: a 'first-order' content can be systematically distorted without the disconnect between it and its reflexive comprehension being the problem at hand. Thus these and other authors seem to offer reasons for a 'strict' conception of pathology that includes first-order systematic disturbances of social reproduction. Those phenomena also demarcate the class of social facts that comes close to the naturalistic connotations of the concept of a pathology and that have traditionally been linked with it. It seems fair to assume that critical social theory might need some sort of conception of those social facts.

In social philosophy, the concept of a pathology has often been employed in circumstances that emphasize either its medical (Canguilhem) or biological (Durkheim) connotations. Such uses might point to disorders that are 'first order,' 'third order' or even render the vocabulary of different orders unnecessary. Thus it seems that the second-order disorder conception cannot account for the influential use of the concept of social pathology but does not challenge that use either. Thus it does not give us an adequate answer to the question previously asked: why should the concept of social pathology be the one to use to define all those phenomena that share the specific relational structure of second-order disorders? 
B) An alternative, then, is to conceive of a social pathology as an 'illness' or 'disease' that infects a society. In contrast to the first conception, here the medical and biological metaphor comes to the fore: instead of regarding pathologies of recognition as 'second order' deviations from recognitive norms implicit in social practices, this perspective takes them to be deviations from the reproductive values or ends of a society.

In the wider tradition of social philosophy, we know this use from classical views such as Durkheim's diagnosis of anomie. Such approaches draw upon a metaphorical conception of the social organism that is supposed to have fallen ill. They thus take pretty literally the pathologyanalogy with a biological vocabulary and the diagnosis-analogy with a medical vocabulary: the society is conceived of as the kind of thing that can fall ill, that is, an "organism"; and human organisms that do fall ill need a physician to diagnose them if they want to get well again. Thus these approaches try to take pretty literally the role of the 'pathologist,' the pathology-diagnostic social theorist, as well.

The idea behind these accounts seems to be roughly that the different social 'organs' appear to be dead or failing in that they do not serve the reproductive end of the social whole. In social and political philosophy this idea can already be seen in Plato's Republic and came to be pervasive for modern social thought through Auguste Comte's Cours de philosophie positive. In the tradition of recognition theory, it might be read as dating back to Hegel's concept of objective spirit. It has been reactualized by Honneth in his recent article on 'The Diseases of Society,' where he states his skepticism about any conception of pathology which does not rely on a rehabilitation of the long-dead idea of a social organism (Honneth, 2014b).

An obvious advantage of this conception is that in contrast to the 'second-order' conception, it clearly delineates the idea of a social pathology as a critical tool in its own right as something which appears next to reification, ideology, invisibilization etc. and not merely as the generic (possibly optional) term for all conceivable social evils beyond mere political and moral wrongs. By taking the biological connotations seriously, it aims at not just any disorders with the suitable 'second-order' structure, but at systematic problems in the reproduction of the recognitive whole. It thereby situates itself within a long tradition of philosophical diagnoses of social pathologies as disturbances on a superindividual, distinctively societal level.

This conception has its disadvantages as well. Many strictly intersubjective disorders or difficulties as dealt with in this special issue (see e.g. Gregoratto's 'Pathology of Love as Gender Domination: Recognition and Gender Identities in Axel Honneth and Jessica Benjamin', or Hietalahti's 'Laughing at Oneself: On the New Interactive Social Character') fall outside 
the picture as they do not build on the idea of a social organism and do not address societal dysfunctions at a macro-level. While those who adhere to the organismic view of pathology may be able to offer sound reasons for not using the concept of social pathology to explicate such disorders, those concerned with such strictly intersubjective disorders might well reply that although the organismic conception is recognition-theoretically construed, as seems implicit in Honneth's latest take on it, it still aims at societal disorders at such a macro-level that it becomes hard to see how they actually work as pathologies of recognition. This might render the organismic conception useless for social-theoretical endeavours such as those presented in this issue, and, symptomatically, none of the articles below make use of it. In contrast to the wide conception of structural 'higher-order disorders,' the organismic view of social pathologies appears to be too narrow for a diagnosis of pathologies of recognition.

A more serious problem concerns the organismic view's socioontological commitments. The view of late-modern capitalist societies according to the model of the social organism has been repeatedly challenged within critical social theory and has even been labelled ideological and, thus, ironically seen as reproducing the pathology it intends to cure, as it casts society in such static terms that it renders radical critique impossible (Adorno, 2003). The papers 'Social Freedom in Contemporary Capitalism: A Reconstruction of Axel Honneth's Normative Approach to the Economy' (Arentshorst) and 'Hegel on Women as Instruments in the Dialectics of the Nation' (Lagerspetz) in this collection criticize certain uses of organismic conceptions in Hegel and Honneth.

C) A third conception of pathology might be seen as attempting to combine the advantages and avoid the difficulties of the previous two. It considers social pathology not via the model of the illnesses of the organism but in terms of the reproductive disturbances in the process of social life. It thus preserves the vitality of the naturalistic metaphor by conceiving society in terms of social life while avoiding the relatively static model of the social organism. This conception can perhaps be seen as implicit in Honneth's early recognition-theoretical account of social pathologies (Honneth, 'Pathologies of the Social', reprinted in Honneth 2007), where he makes extensive use of the concept of social life.

In the wider tradition of recognition theory this use can be found in Hegel's famous transition from 'mere' life via recognition and domination to 'spiritual' life in his Phenomenology of Spirit, in Nietzsche's genealogical account of social illnesses, and perhaps also in Adorno's conception of damaged life. In contemporary recognition theory (Neuhouser 2013 is an 
exception), it is probably at least as uncommon as Honneth's organismic view, which makes an assessment of its disadvantages difficult. In this volume, Arvi Särkelä's article 'Ideology as Artificial Respiration: Hegel on Stoicism, Skepticism, and Unhappy Consciousness' attempts to rehabilitate it.

\section{A Look at the Papers}

The papers in this special issue start with contributions studying the general nature of pathologies of recognition, social pathologies and ideology in general. After that, pathologies in the different spheres are discussed, starting from the sphere of the personal and singular (intimate love, family, the culture of self-ridicule), turning next to issues of civil society (market economy, the ideology of merit, precarious relations of recognition in the practice of social work) and finally, to collective, political and democratic agency (collective agents, the challenge to democracy that unreasonable views pose, and the global ideological conflicts arising from the challenge of labelling others as 'evil'). Diverse explanatory factors such as cultural ideologies or relations of power are variably discussed along the way.

The first three papers analyse the notions of lack of recognition and social pathology. The paper 'Conceptualizing Causes for Lack of Recognition-Capacities, Costs and Understanding' by Heikki Ikäheimo asks why it is the case that people so often fail to give others recognition, or at least adequate recognition. There are several candidates for an explanation. First, it may be that recognition - the giving or receiving of it or both-requires capacities or skills that are not always available. Secondly, it may be that recognition, even though it is (all things considered) good, involves costs, which leads to a reluctance on the part of the participants in the recognition relation. Thirdly and relatedly, even if recognition would be objectively good for the individuals or groups involved, fathoming this, or being able to experience its goodness, especially against experienced costs that it may incur, may nevertheless require intellectual capacities or understanding that individuals do not necessarily possess. The paper explores these different answers against the broadly Hegelian framework of recognition and 'concrete freedom' Ikäheimo has defended elsewhere.

In the paper 'Social Pathologies, Reflexive Pathologies, and the Idea of Higher Order Disorders,' Arto Laitinen critically examines Christopher Zurn's suggestion mentioned above that various social pathologies (pathologies of ideological recognition, maldistribution, invisibilization, rationality distortions, reification and institutionally forced self-realization) 
share the structure of being 'second-order disorders': that is, that they each entail 'constitutive disconnects between first-order contents and secondorder reflexive comprehension of those contents, where those disconnects are pervasive and socially caused' (Zurn, 2011, 345-346). The paper argues that the cases even as discussed by Zurn do not actually match that characterization, but that it would be premature to conclude that they are not thereby social pathologies, or that they do not have a structure in common. It is just that the structure is more complex than originally described, covering pervasive socially caused evils (i) in the social reality, (ii) in the first order experiences and understandings, (iii) in the second order reflection as discussed by Zurn, and also (iv) in the 'third order' phenomenon concerning the pre-emptive silencing or nullification of social criticism even before it takes place.

The paper 'Ideology as Artificial Respiration: Hegel on Stoicism, Skepticism, and Unhappy Consciousness' by Arvi Särkelä draws upon Hegel's analysis of Stoicism, Skepticism and the Unhappy Consciousness as intellectual reactions to social pathology. He argues that, in Hegel's view, the true and the false are held together in ideology by its being recognitively educational: ideology presents both a moment of social pathology and a moment of its overcoming. It gives, so to speak, artificial respiration for a social life fallen ill. The paper argues against two readings of these passages (as distinguished by Robert Stern). For the 'historical materialist' interpretation put forward by Alexandre Kojève, Stoicism, Skepticism and Unhappy Consciousness are treated as servile 'ideologies' and given a 'purely socio-political rationale.' The conceptual realist reading, by contrast, identifies a clear conceptual progress in these shapes as they bring selfconsciousness forth from what initially appeared to be a dead-lock in the preceding relation of Lordship and Bondage. The paper argues that both readings are partly right and partly wrong: the conceptual realist gets it right that Stoicism, Skepticism and Unhappy Consciousness are indeed distinctively novel shapes of consciousness; the historical materialist correctly points out that Stoicism, Skepticism and Unhappy Consciousness are ideologies functionally sustaining the dead equilibrium of Lordship and Bondage. Both aspects can be reconciled by regarding ideology as productive and potentially educative. Ideology works not only to maintain the dead equilibrium of Lordship and Bondage, but also revives the organic means of overcoming it. Thereby this paper argues for the necessity of ideologycritique as a component of an inclusive diagnosis that understands social pathologies as systematic disturbances in the reproduction of characteristically social life. 
The next three papers discuss pathologies of recognition in the relatively intimate spheres of love, family and self-ridicule. Federica Gregoratto, in her article 'Pathology of Love as Gender Domination: Recognition and Gender Identities in Axel Honneth and Jessica Benjamin,' aims at giving a critical account of gender domination by drawing on the concepts of recognition as presented in the work of Axel Honneth and Jessica Benjamin. Gender domination is here understood as a pathology of love, which concerns especially the heterosexual sentimental bond. The argumentation proceeds in three steps. First, it reconstructs, via Honneth, the type of social normativity regulating relations of loving recognition, which is identified as a normativity of interdependence. Accordingly, love partners are both dependent on and independent from each other. Second, by relying on Benjamin, Gregoratto argues that the interdependence bond is to be understood as implying mutual exercises of power: power is a positive feature in the transformative process of recognition qua love. Third, the pathology of loving recognition is framed as a disruption of the interdependence relation, due to the emergence of a sharp opposition between identities of 'man' and 'woman' - namely between an identity privileging independence and an identity privileging dependence respectively as their particular constitutive features. Gender domination consists then in the unilateral exercise of power that blocks the transformative force of love.

Sari Roman-Lagerspetz's paper 'Hegel on Women as Instruments in the Dialectics of the Nation' adds a new line to Feminist critiques of Hegel. The paper starts with the observation that Feminist critics often emphasize women's exclusion from the public sphere in Hegel's account, but that less attention is paid to the way Hegel sees the role of family ethics, the guardians of which are women, as constitutive for the dialectics of the nation. The paper argues that gender hierarchy is necessary for Hegel's rational state. For this reason, recognition can never become fully universal for Hegel. The paper argues that Hegel's view of women as not-fully-rational beings, and his uncritical acceptance of the system of nation-states, are interconnected. These aspects of Hegel's system are for good reason often found less appealing; it is an important observation that they are interrelated. Implicitly, the paper challenges contemporary defenders of universal recognition to do better than Hegel in these respects in trying to combine universal recognition with recognition of such particularities as gender and nationality.

The paper 'Laughing at Oneself: On the New Social Character' by Jarno Hietalahti examines certain practices of humour, especially selfridicule, as a kind of social pathology, drawing on the work of Erich Fromm. The paper starts with the observation that laughing at oneself is typically 
considered to be a positive trait. In general, self-ridicule reveals that the joker does not consider him- or herself to occupy a high ground, to be above ridicule. This kind of affirmative attitude towards laughing at oneself is also present in many philosophers' thinking. Morally, it is stated, it is better to laugh at oneself than at others. The paper challenges some of these general ideas. Not every kind of self-ridiculing is positive. Laughing at oneself can eventually be problematic in relation to recognizing oneself and others (this is not unrelated to the forms of pathology discussed by Honneth as pathologies of legal and moral freedom - they provide a protected 'leave' from the social world, which is important, but can turn pathological if it turns into an obstacle to ordinary participation in the social world. The same goes for excessive self-irony as a form of distancing oneself not only from the social world, but from one's own orientation in life). The critique is based on Erich Fromm's social philosophy, especially contemporary versions of Fromm's notion of 'social character.'

The next three papers discuss issues in civil society, such as market economy, the ideology of merit and precarious relations of recognition in the practice of social work. In his paper 'Social Freedom in Contemporary Capitalism: A Reconstruction of Axel Honneth's Normative Approach to the Economy' Hans Arentshorst discusses two related issues, namely how to adequately describe the economy within the framework of a critical social theory, and how to understand the interrelation between the socio-economic and political dimensions of democracy. Concerning the first issue Honneth stresses the moral quality of social integration, and concerning the second issue he develops a conception of 'democratic Sittlichkeit.' In reconstructing these issues, both the promises and problems of Honneth's work for analyzing and criticizing contemporary developments in the economy are explored. The paper concludes that the unresolved challenge for Honneth is not to succumb to a nostalgic return to $19^{\text {th }}$ century solutions - a nostalgia that can also be found in the recent article where Honneth (2014b) argues for a return to an organic conception of society - but to combine the insights of Hegel and Durkheim concerning our fundamental interdependence with insights concerning the new emancipatory aspects of contemporary forms of individualism.

Heidi Elmgren's paper 'Recognition and the Ideology of Merit' discusses pathological forms that the ideal of merit takes in ideological uses of meritocratic ideas. According to the French philosopher Dominique Girardot (2011) the possibility of our genuinely recognizing one another is impaired by the ideology of merit: this new ideology standardizes recognition and forces competition, thus creating hierarchies and what Axel 
Honneth calls social pathologies. The ideology also threatens the category of action in Hannah Arendt's (1958) sense. The paper elucidates Girardot's stance and sketches a comparison between Honneth's and Girardot's views on recognition. Despite the explicit connection to Honneth's theory, Girardot actually creates an Arendtian theory of recognition. It is against the background of that theory that the pathological forms of contemporary meritocracy best come to light.

In Petteri Niemi's article 'The Professional Form of Recognition in Social Work,' the theory of recognition is applied to the context of social work, where relations of recognition can easily be strained due to the differences in status, power, and vulnerability to stigmatization. A specific form of recognition suitable for professional contexts is outlined and defended. The professional form of recognition is an essential part of efficient and ethical professional support to human development and well-being, in social work but also in many other helping and teaching professions. This form of recognition involves respect, esteem and care for clients. These attitudes contribute to the self-respect, self-esteem and self-love of the clients. On the other hand, professional disrespect, disesteem and indifference may deeply harm the self-feelings and self-relations of clients.

The last three papers discuss collective recognition and the political and democratic challenge of facing allegedly unreasonable or evil others. In the paper 'Political liberalism and the preventive containment of unreasonable beliefs and behavior' Joonas Pennanen examines the ways in which illiberal and unreasonable views can be legitimately contained in a politically liberal society, and discusses some of the pressing reasons to undertake, or abstain from, such measures. Theoretical background for the discussion is provided by Rawlsian political liberalism. The paper focuses on the particular justification for the preventive containment of unreasonable views offered by Jonathan Quong (2011). It is claimed that Quong's approach raises some significant worries (not unrelated to the 'third-order pathologies' discussed above in Chapter 2). The suggestion is put forward that political liberals would do well to pay more attention to respect and relations of recognition.

Onni Hirvonen's paper 'Pathologies of Collective Recognition' maps the theoretical possibilities of what pathologies of collective recognition might be. It argues that collectives have a twofold role in recognition: they can function either as normative frameworks that enable recognition, or as agents of recognition. From this it follows that pathologies of collective recognition can be either systemic or agential. Furthermore, accepting the agential role of collectives opens possibilities for specific forms of 
pathologies. The paper concludes with remarks on the ontological commitments that need to be made if one wants to understand pathologies of recognition as including collective agents.

Olli Pitkänen's paper '(Pathologies of) Recognition in Schelling's Thought on Evil' departs from the observation that there is on several levels a growing antagonism in our society between two opposite mentalities: a liberal, universalistic mentality that trusts in rationality (termed 'McWorld' by political theorist Benjamin Barber in Barber, 1992), and a conservative mentality that relies on the weight of tradition (Barber's term for this is 'Jihad'). The argument in this paper is that these mentalities are not absolutely incompatible, but that the hostility between them results largely from fundamental internal inconsistencies that are suppressed and projected onto the other. In explicating this argument, the paper uses F.W.J. Schelling's (1992 [1809]) metaphysical theory of evil, as a theory of recognition, where great emphasis is put on self-recognition as a condition for proper recognition of the other.

\section{Bibliography}

Adorno, T. W. (2003) 'Beitrag zur Ideologienlehre,' in T. Adorno Gesammelte Schriften Vol. 8, Frankfurt am Main: Suhrkamp Verlag

Arendt, H. (1998 [1958]) The Human Condition (2 ${ }^{\text {nd }}$ ed.) Chicago: University of Chicago Press

Barber, B. (1992) 'Jihad vs. McWorld' The Atlantic March 1992, viewed 31 October 2014, available at:

http://www.theatlantic.com/magazine/archive/1992/03/jihad-vsmcworld/303882/

Benjamin, J. (1988) Bonds of Love Pantheon Books

Boltanski, L. \& Chiapello, E. (2005) The New Spirit of Capitalism London: Verso Publishing

Bristow, W. F. (2007) Hegel and the Transformation of Philosophical Critique Oxford: Oxford University Press

Butler, J. (1997) The Psychic Life of Power Stanford: Stanford University Press 
Butler, J (2008) 'Taking Another's View - Ambivalent Implications' in A. Honneth Reification, Oxford: Oxford University Press

Canguilhem, G. (1991 [1943/1966]) The Normal and The Pathological trans. C. R. Fawcett \& R.S. Cohen, Zone Books, New York

Canivez, P. (2011) 'Pathologies of Recognition' Philosophy and Social Criticism, vol. 37 , no. 8 , pp. $851-887$

Claassen, R. (2014) 'Social Freedom and the Demands of Justice: A Study of Honneth's Das Recht der Freiheit' Constellations, vol. 21, pp. 67-82

Dewey, J. (1994 [1927]) The Public and its Problems Athens: Shallow Press

Durkheim, E. (1951 [1897]) Suicide: a Study in Sociology New York: The Free Press

Fichte, J. G. (2000 [1796]) Foundations of Natural Right Cambridge: Cambridge University Press

Fraser, N. (1995) 'From Redistribution to Recognition? Dilemmas of Justice in a "Post-Socialist" Age' New Left Review, no. 212, pp. 67-93

Fraser, N. \& Honneth, A. (2003) Redistribution of Recognition - A PoliticalPhilosophical Exchange London: Verso Books

Freyenhagen, F. (2015) 'Honneth on Social Pathologies: a Critique' Critical Horizons, vol. 16, no. 2, pp. $131-152$

Fromm, E. (2000) 'Human Nature and Social Theory' Fromm Forum 4/2000, Tübingen: International Erich Fromm Society

Girardot, D. (2011) La Société du mérite - Ideologie méritocratique E violence néoliberale Bord de l'Eau, Lormont

Green, A. (1999) The Work of the Negative London, New York: Karnac

Hegel, G. W. F. (1977 [1807]) Phenomenology of Spirit Oxford: Clarendon Press

Hegel, G. W. F. (1991 [1820]) Elements of the Philosophy of Right (ed. A. W. Wood, trans. H. B. Nisbet), Cambridge: Cambridge University Press 
Honneth, A. (1995 [1992]) The Struggle for Recognition Cambridge: MIT Press

Honneth, A. (2002) 'Grounding Recognition: A Rejoinder to Critical Questions' Inquiry vol. 45, no. 4, pp. 499-519

Honneth, A. (2006) 'Facetten des vorsozialen Selbst. Eine Erwiderung auf Joel Whitebook' in T. Altmeyer (ed) Die vernetzte Seele. Die intersubjektive Wende in der Psychoanalyse Stuttgart: Clett-Cotta

Honneth, A. (2007) 'Pathologies of the Social: The Past and Present of Social Philosophy' Disrespect: The Normative Foundations of Critical Theory Cambridge: Polity Press, pp. 3-48

Honneth, A. (2008) Reification Oxford: Oxford University Press

Honneth, A. (2011) 'Rejoinder' in Axel Honneth: Critical Essays. With a Reply by Axel Honneth (ed. D. Petherbridge), Brill, 391-422

Honneth, A. (2014a [2011]) Freedom's Right. The Social Foundations of Democratic Life (trans. Joseph Ganahl), New York: Columbia University Press

Honneth, A. (2014b) ‘Diseases of Society: Approaching a Nearly Impossible Concept' Social Research: An International Quarterly vol. 81, no. 3, pp. 683-703

Ikäheimo, H. (2002) 'On the Genus and Species of Recognition' Inquiry vol. 45 , no. 4 , pp. $447-462$

Ikäheimo, H. (2014) Anerkennung Berlin/Boston: Walter de Gruyter

Ikäheimo, H. \& Laitinen, A. (2007) Dimensions of Personhood Charlottesville: Imprint Academic

Ikäheimo, H. \& Laitinen, A. (eds.) (2011) Recognition and Social Ontology Leiden: Brill

Jaeggi, R. (2009) ‘Was ist Ideologiekritik?' in R. Jaeggi \& T. Wesche (eds.) Was ist Kritik? Frankfurt am Main: Suhrkamp Verlag, pp. 266-295

Kojève, A. (1969) Introduction to the Reading of Hegel: Lectures on the Phenomenology of Spirit Ithaca: Cornell University Press 
Kotkavirta, J. (1993) Practical Philosophy and Modernity Jyväskylä: University of Jyväskylä

Laitinen, A. (2002) 'Interpersonal Recognition: A Response to Value or a Precondition of Personhood?' Inquiry vol. 45, no. 5, pp. 463-478

Laitinen, A. (2010) 'On The Scope of "Recognition": The Role of Adequate Regard and Mutuality' in H.-C. Schmidt am Busch \& C. Zurn (eds.) The Philosophy of Recognition. Historical and Contemporary Perspectives Lanham: Lexington Books, pp. 319-342

Marcuse, H. (1955) Reason and Revolution: Hegel and the Rise of Social Theory London: Routledge

Markell, P. (2003) Bound by Recognition Princeton: Princeton University Press McNay, L. (2008) Against Recognition Cambridge: Polity Press

Mitchell, S. (1988) Relational Concepts in Psychoanalysis: An Integration Cambridge, Mass.: Harvard University Press

Neuhouser, F. (2000) Actualizing Freedom: the Foundations of Hegel's Social Theory Cambridge, Mass.: Harvard University Press

Neuhouser, F. (2013) 'Hegel on Life, Freedom, and Social Pathology' A. Honneth \& G. Hindrichs (eds) Freiheit Frankfurt am Main: Vittorio Klostermann

Probst, B. (1989) 'Pathologie' Historisches Wörterbuch der Philosophie (ed. K. Gründe), pp. 182-191

Quong, J. (2011) Liberalism Without Perfection Oxford: Oxford University Press

Ricoeur, P. (2006) The Course of Recognition Cambridge: Harvard University Press

Särkelä, A. (2013) 'Ein Drama in drei Akten. Der Kampf um öffentliche Anerkennung bei Dewey und Hegel' Deutsche Zeitschrift für Philosophie vol. 61, no. 5/6, pp. 681-696 
Schelling, F. W. J. (1992 [1809]) Philosophical Inquiries into the Nature of Human Freedom (trans. J. Gutmann), Open Court, USA

Schmidt am Busch, H.-C., Zurn, C. F. (eds.) (2010) The Philosophy of Recognition. Historical and Contemporary Perspectives Lanham: Lexington Books

Stern, D. (1985) The Interpersonal World of the Infant New York: Basic Books

Stern, R. (2002) Hegel and the Phenomenology of Spirit London: Routledge

Taylor, C. (1994) 'The Politics of Recognition' in A. Guttman (ed.) Multiculturalism: Examining the Politics of Recognition Princeton: Princeton University Press

Thompson, S. (2006) The Political Theory of Recognition: A Critical Introduction Cambridge: Polity Press

Thompson, S. \& Yar, M. (2011) The Politics of Misrecognition Farnham: Ashgate Tomasello, M. (2009) Why We Cooperate Cambridge: MIT Press

Tully, J. (2000) 'Struggles over Recognition and Distribution' Constellations vol. 7 , no. 4 , pp. 469-482

Whitebook, J. (1995) Perversion and Utopia Cambridge: MIT Press

Whitebook, J. (2006) 'Die Arbeit des Negativen und die Grenzen des 'intersubjektiven Turne'. Eine Erwiderung auf Axel Honneth' in M. Altmeyer \& H. Thomä (eds.) Die vernetzte Seele. Die intersubjektive Wende in der Psychoanalyse Stuttgart: Clett-Cotta

Whitebook, J. (2009) Der Gefesselte Odysseus Frankfurt, New York: Campus Verlag

Wildt, A. (2010) 'Recognition in Psychoanalysis' in H.-C. Schmidt am Busch \& C. Zurn (eds.) The Philosophy of Recognition. Historical and Contemporary Perspectives pp. 189-210

Williams, R. R. (1992) Recognition - Hegel and Fichte on the Other SUNY Press 
Zurn, C. F. (2011) 'Social Pathologies as Second-Order Disorders' in D. Petherbridge (ed.) Axel Honneth: Critical Essays. With a Reply by Axel Honneth Leiden: Brill

\section{Endnotes}

${ }^{1}$ The research project 'Pathologies of Recognition' is funded by the Academy of Finland and hosted by the University of Jyväskylä. See e.g. Kotkavirta, 1993; Ikäheimo, 2002; Laitinen, 2002; Honneth, 2002; Ikäheimo \& Laitinen, 2007; Laitinen, 2010; Ikäheimo \& Laitinen (eds.), 2010; Ikäheimo, 2014. Despite the moniker, the contributors are currently located not only in Jyväskylä but also in Tampere, Sydney, Frankfurt, Lucerne, St.Gallen, and Helsinki.

2 Honneth's conception of the deontological dimension is somewhat different. See Ikäheimo, 2014, chapter 6.

${ }^{3}$ The third, naturalist conception of social pathology (Nietzsche, Adorno, the Hegel of Phenomenology of Spirit and Dewey) does not accept a clear distinction between natural and social causation. However, they would all maintain that social pathologies have their roots in pre-human nature.

${ }^{4}$ Indeed, most papers in this collection belong to this approach in critical social philosophy, not stressing the medical or biological connotations of pathologies of recognition, but nonetheless stressing the pervasive and socially produced character of the social evils in question. 